\title{
On-line Solid Phase Extraction of Nickel, Copper, and Cadmium Using a Newly Synthesized Polyamine Silica Gel-loaded Mini-column for Flame Atomic Absorption Spectrometric Determination
}

\author{
Sezen Sivrikaya ${ }^{\mathrm{a}, \mathrm{b} *}$, Mustafa Imamoglua $^{\mathrm{a}}$, and Derya Kara ${ }^{\mathrm{c}}$ \\ ${ }^{a}$ Sakarya University, Sciences and Arts Faculty, Chemistry Department, 54187 Sakarya, Turkey \\ b Bülent Ecevit University, Engineering Faculty, Environmental Engineering Department, \\ 67100 Zonguldak, Turkey \\ c Balikesir University, Sciences and Arts Faculty, Chemistry Department, 10100 Balikesir, Turkey
}

\begin{abstract}
In this study, polyamine (pentaethylene hexamine) functionalized silica gel (PA-SG) was prepared as a novel sorbent material for on-line preconcentration of $\mathrm{Cd}(\mathrm{II}), \mathrm{Cu}(\mathrm{II})$, and $\mathrm{Ni}$ (II) from complex matrices. The PA-SG was characterized by means of elemental analysis and FT-IR spectroscopic techniques. The effective parameters for on-line preconcentration and separation of Cd(II), $\mathrm{Cu}(\mathrm{II}), \mathrm{Ni}(\mathrm{II})$, and FAAS detection were optimized by investigating the effects of sample $\mathrm{pH}$, type, and concentration of eluent, flow rate of sample and eluent, loop volume, and matrix ions. The linear range of the proposed method was between 10-200 $\mu \mathrm{g}$ $\mathrm{L}^{-1}$ for each element, with enrichment factors of 39.9, 30.4, and 43.6 and detection limits of 0.19 , 0.73 , and $0.91 \mu \mathrm{g} \mathrm{L}^{-1}$ for $\mathrm{Cd}(\mathrm{II})$,
\end{abstract}

$\mathrm{Cu}(\mathrm{II})$, and $\mathrm{Ni}(\mathrm{II})$, respectively, by loading $5.0 \mathrm{~mL}$ of sample solution.

The precision of the method (evaluated as the relative standard deviation obtained after analyzing 11 samples with three replicates each) was determined as 3.2, 2.4, and $4.0 \%$ for $20 \mu \mathrm{g} \mathrm{L}^{-1}$ of $\mathrm{Cd}(\mathrm{II})$, $0.1 \mathrm{mg} \mathrm{L}^{-1}$ of $\mathrm{Cu}(\mathrm{II})$ and $\mathrm{Ni}(\mathrm{II})$, respectively, by loading $5.0 \mathrm{~mL}$ of sample solution. The sorption capacities of PA-SG were 41.4, 33.1 , and $23.7 \mathrm{mg}$ for $\mathrm{Cd}(\mathrm{II})$, $\mathrm{Cu}(\mathrm{II})$, and $\mathrm{Ni}$ (II) per gram of resin, respectively. The accuracy of the proposed on-line preconcentration procedure was evaluated by analyzing reference materials CTA-VTL-2 Virginia Tobacco Leaves and NWTM-15.2 Water - Trace Elements. Application of the proposed procedure was successfully accomplished for the analysis of natural water and food samples.

\section{INTRODUCTION}

Heavy metals such as Cd(II), $\mathrm{Cu}(\mathrm{II})$, and $\mathrm{Ni}(\mathrm{II})$ began to cause greater damage to human health, the environment, and aqueous media with the development of industry (1-5). Due to the wellknown toxic effects of these metal ions for human beings, their deter-

\footnotetext{
* Corresponding autbor.

E-mail: sezenskaya@gmail.com

Tel: +902642956773 or

$+903722613287$

Fax: +903722613276
}

mination at trace levels in environmental water samples, food stuffs, and air, they are a very important topic in analytical chemistry (6-8).

The detection techniques of flame atomic absorption spectrometry (FAAS), graphite furnace flame atomic absorption spectrometry (GFAAS), inductively coupled plasma optical emission spectrometry (ICP-OES), and inductively coupled plasma mass spectrometry (ICP-MS) are widely used for the determination of metal ion levels.
Although some of them are very sensitive for the determination of low levels of metals, there is still the need for a separation and/or preconcentration procedure before the measurement step due to matrix effects and low levels of the analytes in the samples (9-11). Therefore, a preconcentration and/or separation step should be carried out before the measurement step. The widely used preconcentration methods include co-precipitation (12), solid phase extraction (13-19), cloud point extraction (20), and solvent extraction (21).

Solid phase extraction (SPE) has many advantages such as simplicity, reliability, high concentration factor, ease of automation, rapid phase separation, speed, environmental friendliness, and short analysis time compared with other preconcentration methods (22-27). SPE can be carried out in the on-line and offline mode. The latter mode is a classical column technique based on passing the sample through the column using a peristaltic pump, positive pressure, or under gravity. This technique is very time-consuming (e.g., 20 minutes) and requires a high sample volume $(100 \mathrm{~mL})$. Online SPE creates a very powerful technique for trace elements and has a number of advantages including high sampling frequency, reduction of operator error due to the use of a closed system, high analytical efficiency, more reliable results, short analysis time, low cost, low consumption of sample and solvents, effective separation 
from matrices, high sampling rate, and easy regeneration of the solid phase $(16,24,28,29)$.

Although many sorbents have been reported for SPE of metal ions such as activated carbon (30), polymeric resin (31), chelating resin (32), carbon nanotubes $(33,34)$, natural adsorbents (35), modified silica gel $(36,37)$, and ion exchange resins (38), many of them have been tested in the off-line SPE mode. The usability of the sorbent in the on-line mode is dependent on the metal uptake and the release performance of the material. The sorbent should have a fast kinetics of metal uptake and elution of the metal ions should be done with a minimal volume of eluent. Hence, the synthesis of a novel sorbent material having the desired properties for the on-line SPE procedure is very important.

Some sorbents, such as manganese oxide particles dispersed in a silica matrix (39), bond Elut Plexa ${ }^{\mathrm{TM}}$ PCX polymer resin (40), SDS coated alumina modified with dithizone (41), Amberlite ${ }^{\circledR}$ XAD-4 resin impregnated with nalidixic acid (42), 6-(2thienyl)-2-pyridinecarboxaldehyde functionalized Amberlite XAD-4 resin (43), Toyopear ${ }^{\circledR}$ AF Chelate$650 \mathrm{M}$ resin (44), and magnetic nanoparticles functionalized with 4 '-aminobenzo-15-crown-5-ether (45), have been tested recently for on-line preconcentration of some trace elements.

In this study, a polyamine (pentaethylene hexamine) functionalized silica gel (PA-SG) was synthesized and characterized by $\mathrm{CHN}$ elemental analysis and FT-IR spectrometry. The performance of the PA-SG for on-line SPE of Cd(II), $\mathrm{Cu}(\mathrm{II})$, and $\mathrm{Ni}$ (II) ions were evaluated. The effects of the sample $\mathrm{pH}$, eluent, sample and eluent flow rate, eluent volume, potentially interfering ions, and sorption capacity of the resin were investigated and optimized. Then, this system was applied to water and food samples and certified reference materials for validation of this method.

\section{EXPERIMENTAL}

\section{Instrumentation}

The measurements of the metal levels were performed with a Shimadzu AA6701F flame atomic absorption spectrometer (FAAS) (Shimadzu Corporation, Kyoto, Japan). The FAAS instrumental and operating conditions that provided the best sensitivity for $\mathrm{Cd}(\mathrm{II}), \mathrm{Cu}(\mathrm{II})$, and $\mathrm{Ni}$ (II) are listed in Table I. The analytical signals were measured as peak height. All experiments were conducted in triplicate and the averages of the results are presented in this study. The elemental analyses of the modified silica gels were determined using a LECO elemental analyzer (LECO Corporation, St. Joseph, MI, USA). KBr pellets were used for the FT-IR measurements of the silica gel samples using the PerkinElmer ${ }^{\circledR}$ FT-IR spectrometer (PerkinElmer, Shel-

\section{Atomic Apectroscopy 1 Vol. 35(4), July/August 2014}

ton, CT, USA). A Schott Model CG 840 pH meter (Schott AG, Mainz, Germany) was used to adjust the $\mathrm{pH}$ of the sample solutions. An Ismatec peristaltic pump (ColeParmer, USA) with four channels connected with Tygon ${ }^{\circledR}$ and polyethylene tubings was used to pass the solutions through the minicolumn. The flow system had an Omnifit ${ }^{\circledR}$ PVCs mini-column (Omnifit, Cambridge, UK) (0.4 mm i.d., $6.0 \mathrm{~cm}$ long) and 2 two-way valves. The flow injection system is shown in Figure 1. Digestion of the certified reference materials and the food were carried out by microwave radiation using an Ethos Plus microwave oven (Milestone, Sorisole, Italy) which reaches an output of 1000 W. A PerkinElmer ${ }^{\circledR}$ NexION® 300D inductively coupled plasma mass spectrometer (ICP-MS) (PerkinElmer Inc., Shelton, CT, USA) was used for the determination of the $\mathrm{Cd}(\mathrm{II}), \mathrm{Cu}(\mathrm{II})$, and $\mathrm{Ni}$ (II) levels in real water samples.

TABLE I

FI-FAAS Conditions for Measurement of $\mathrm{Cd}(\mathrm{II}), \mathrm{Cu}(\mathrm{II})$, and $\mathrm{Ni}$ (II)

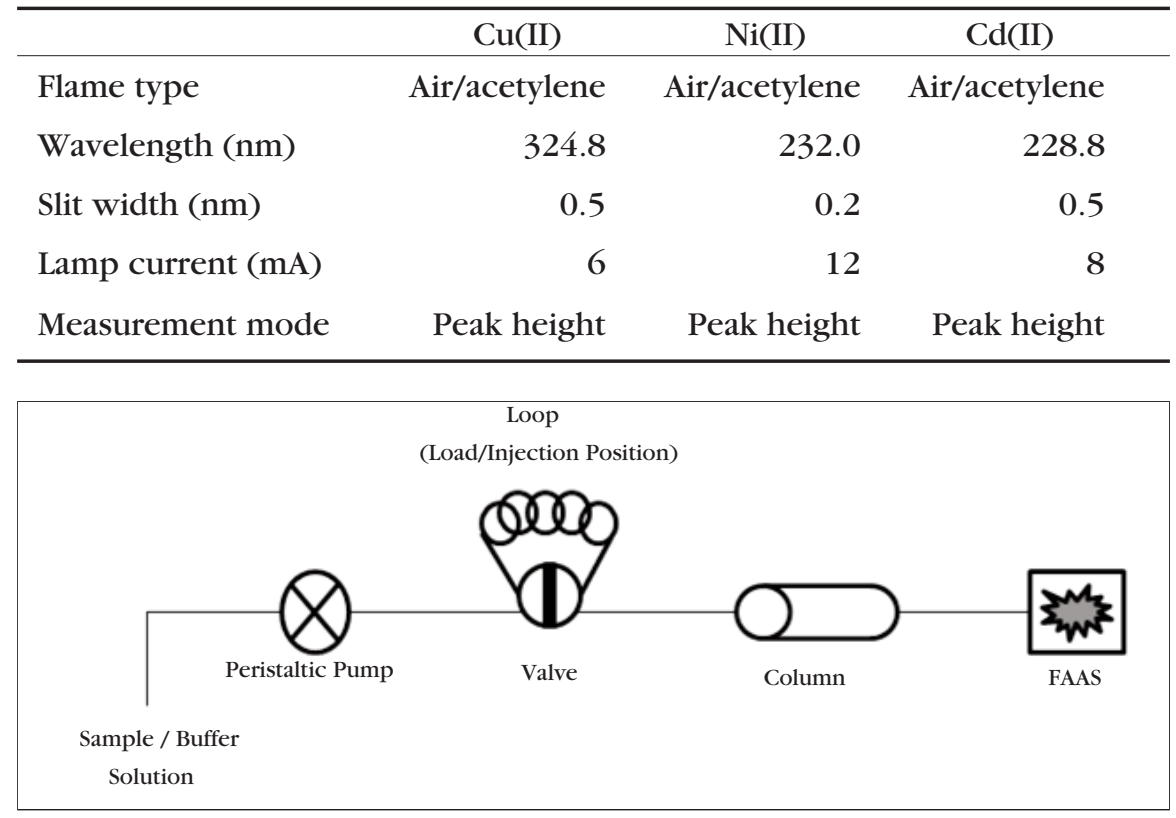

Fig. 1. The flow injection system used for the measurement of $C d(I I), C u(I I)$ and Ni(II) levels by FAAS. 


\section{Reagents and Standard Solutions}

The chemicals used in this study were of analytical reagent grade. Deionized water with a chemical resistivity of $18 \mathrm{M} \Omega \mathrm{cm}^{-1}$ was used in all analyses without further purification. The working standard solution were prepared by stepwise dilution from $1000 \mathrm{mg} \mathrm{L}^{-1}$ Cd(II), $\mathrm{Cu}(\mathrm{II})$, and $\mathrm{Ni}(\mathrm{II})$ stock standard solutions (Merck KGaA, Darmstadt, Germany). These stock standards were used to prepare the calibration standards by dilution before use on a daily basis. A buffer solution was prepared from ammonium acetate and ammonia (Merck KGaA, Darmstadt, Germany) adjusted to the appropriate $\mathrm{pH}$ of 7.0 and 8.0. Other $\mathrm{pH}$ solutions were adjusted by adding diluted hydrochloric acid or sodium hydroxide (Merck KGaA, Darmstadt, Germany) solution. Two certified reference materials, CTAVTL-2 Virginia Tobacco Leaves (Institute of Nuclear Chemistry and Technology, Poland) and NWTM15.2 Water - Trace Elements (LGC Standards, UK), were used in this study for testing the accuracy of the proposed method.

\section{Synthesis of PA-SG}

Five grams of silica gel were activated in concentrated hydrochloric acid for four hours, then filtered off and washed several times with deionized water. Then, the silica gel was dried at $150{ }^{\circ} \mathrm{C}$ for 24 hours. The activated silica ( $5 \mathrm{~g}$ ) was reacted with 3-chloropropyltrimethoxysilane $(5 \mathrm{~mL})$ in $50 \mathrm{~mL}$ of anhydrous toluene. The product, 3-chloropropyl bonded silica gel, was filtered and washed with toluene, ethanol, and diethyl ether, respectively, and dried at $60^{\circ} \mathrm{C}$ for six hours. The 3-chloropropyl bonded silica gel was mixed with $6 \mathrm{~mL}$ of triethylamine and $5 \mathrm{~mL}$ of pentaethylene hexamine in $50 \mathrm{~mL}$ of dry toluene, and mechanically stirred for 24 hours under nitrogen atmosphere. At the end, the prod- uct of polyamine (pentaethylene hexamine) functionalized silica gel (PA-SG) was filtered off and washed with toluene, ethanol, and diethyl ether, and dried at $60^{\circ} \mathrm{C}$ for four hours $(18,25,46)$. The proposed structure of the modified silica is given in Figure 2.

\section{On-line SPE Operating Procedure}

The on-line SPE system consists of a peristaltic pump fitted with Tygon ${ }^{\circledR}$ tubes, a glass mini-column, and a valve with a load and inject position. The mini-column was loaded with PA-SG. The on-line system is directly connected to the nebulizer of the FAAS. Firstly, the valve was set to the loading position. Then a buffer solution (ammonium acetate and ammonia) was passed through the mini-column at $5 \mathrm{~mL} \mathrm{~min}-1$ for 30 seconds, and the sample solution at $\mathrm{pH} 8.0$ was then

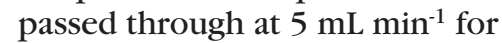
60 seconds. In this process, Cd(II), $\mathrm{Ni}(\mathrm{II})$, and $\mathrm{Cu}$ (II) were retained on the mini-column. Then, deionized water was passed through the minicolumn at $5 \mathrm{~mL} \mathrm{~min}^{-1}$ for 30

seconds in order to eliminate the matrix ions. After sample loading and cleaning, the eluent solution was loaded into the loop. The valve was shifted to the inject position and the eluent passed through the column at $5 \mathrm{~mL} \mathrm{~min}^{-1}$. The eluent containing the analyte was pumped directly into the flame atomic absorption spectrometer for determination of the metal ions. After this cycle, the mini-column was cleaned with deionized water for 30 seconds and the other operation for the next sample was started. This procedure is given in Table II. In these studies, flow rates higher

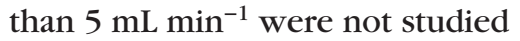
because the maximum operating limit of the pump using this tubing

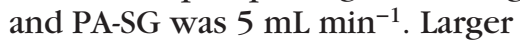
I.D. tubing and/or large-grained silica could provide an opportunity to test higher flow rates.

\section{Sample Preparation}

The proposed method was employed for the determination of the $\mathrm{Cd}(\mathrm{II}), \mathrm{Cu}(\mathrm{II})$, and $\mathrm{Ni}(\mathrm{II})$ levels in some food and environmental water samples and includes river, stream, lake, and tap water. River water was collected from the Sakarya River, tap water from a house in Sakarya, and seawater from the Zonguldak coast on the Black Sea and the Izmit Gulf in the Marmara Sea, Turkey. The water samples were acidified with $\mathrm{HNO}_{3}$

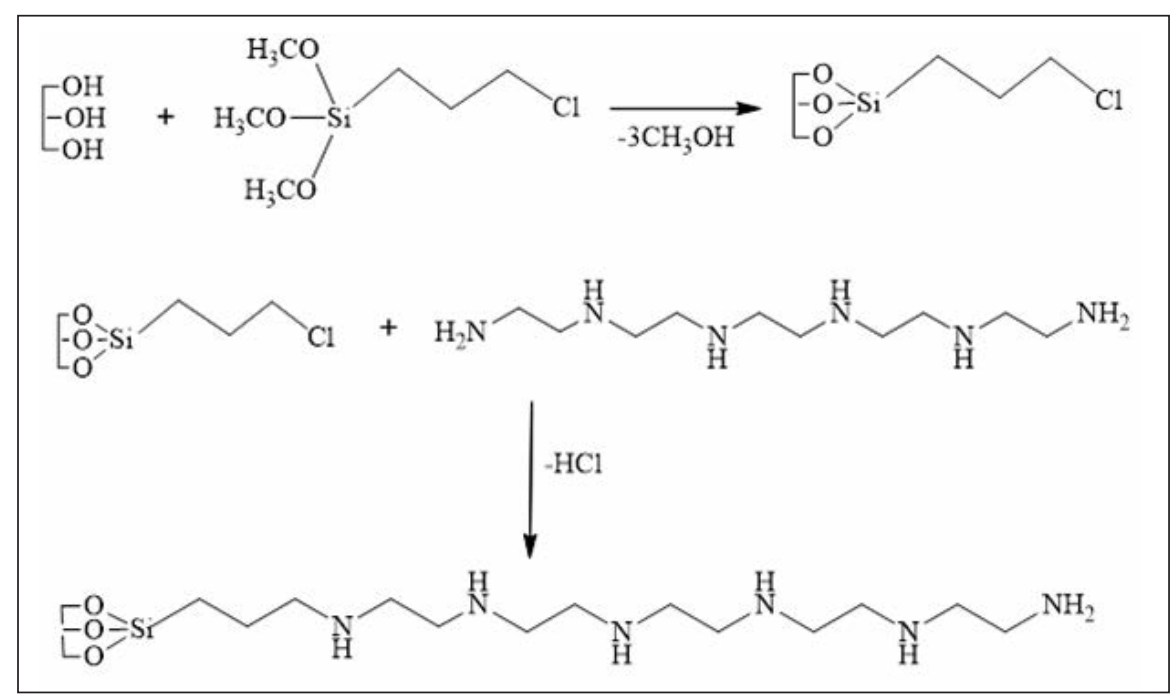

Fig. 2. Synthesis of 3-chloropropyl and polyamine bonded silica gel. 


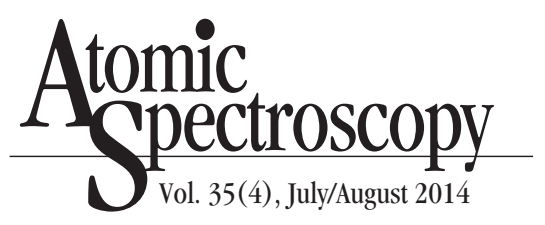

to a $\mathrm{pH}$ of 1.0 and then quickly filtered using a $0.45 \mu \mathrm{m}$ cellulose acetate membrane. Then, the level of $\mathrm{Cd}(\mathrm{II}), \mathrm{Cu}(\mathrm{II})$, and $\mathrm{Ni}$ (II) in the samples was determined by the proposed method.

Food samples such as chicken and tea were purchased from various supermarkets in Sakarya, Turkey. Digestion of these samples was performed by a microwave digestion technique. About $0.5 \mathrm{~g}$ of food samples were treated with $7 \mathrm{~mL}$ of $65 \%$ (v/v) nitric acid solution and $1 \mathrm{~mL}$ of $30 \%(\mathrm{v} / \mathrm{v}) \mathrm{H}_{2} \mathrm{O}_{2}$ solution. The mixtures were weighed into Teflon flasks and kept at rest for 20 minutes, followed by digestion with microwave radiation in four stages under the following conditions: Stage 1: power of $250 \mathrm{~W}$, temperature $180{ }^{\circ} \mathrm{C}$ for 1 minute, Stage 2: power of $0 \mathrm{~W}$, temperature $180{ }^{\circ} \mathrm{C}$ for 1 minute, Stage 3 : power of $250 \mathrm{~W}$, temperature $200{ }^{\circ} \mathrm{C}$ for 5 minutes, and Stage 4 : power of $400 \mathrm{~W}$, temperature $210^{\circ} \mathrm{C}$ for 5 minutes. After digestion, the solutions were cooled at room temperature and the concentrations of $\mathrm{Cd}(\mathrm{II}), \mathrm{Cu}(\mathrm{II})$, and $\mathrm{Ni}(\mathrm{II})$ in the obtained solutions were determined using the proposed method. The certified reference material CTAVTL-2 Virginia Tobacco Leaves was prepared in the same way as the food samples.

Synthetic seawater that contained specific amounts of sodium, magnesium, potassium, and calcium was prepared by adding the necessary amounts of chloride salts of these elements. The synthetic seawater was composed of $10,500 \mathrm{mg} \mathrm{L}^{-1}$ sodium, $1350 \mathrm{mg} \mathrm{L}^{-1}$ magnesium, $400 \mathrm{mg} \mathrm{L}^{-1}$ calcium, and $380 \mathrm{mg} \mathrm{L}^{-1}$ potassium (47).

\section{RESULTS AND DISCUSSION}

\section{Characterization of PA-SG Sorbent}

The FT-IR transmittance spectra of the activated silica gel, 3-chloropropyl-bonded silica gel, and PA-SG are shown in Figure 3. In activated silica gel, the peak in the spectral range at $3476 \mathrm{~cm}^{-1}$ is -OH stretching, around $1642 \mathrm{~cm}^{-1}$ it is $-\mathrm{OH}$ deformation, while $1092 \mathrm{~cm}^{-1}$ and $796 \mathrm{~cm}^{-1}$ correspond to the stretching and bending of the Si-O-Si bonds, and $960 \mathrm{~cm}^{-1}$ is stretching of Si-OH, respectively. In the FT-IR transmittance spectra of the 3-chloropropyl-bonded silica gel, the $\mathrm{C}-\mathrm{H}$ stretching bands of the bonded alkyl groups are at 2857 $\mathrm{cm}^{-1}$, the aliphatic $\mathrm{C}-\mathrm{H}$ deformation bands of these groups and C-C stretching weak bands are within the range at $1500-1350 \mathrm{~cm}^{-1}$, and stretching of $\mathrm{Si}-\mathrm{O}$ is at $1100 \mathrm{~cm}^{-1}$. In the FT-IR transmittance spectra of PA-SG, the bands at 2953 and $2855 \mathrm{~cm}^{-1}$ are $\mathrm{C}-\mathrm{H}$ stretching at $\mathrm{CH}_{2} \mathrm{CH}_{2} \mathrm{NH}_{2}$ and at1649 and 1478 $\mathrm{cm}^{-1}$ are $\mathrm{C}-\mathrm{H}$ deformation bands of these groups.
TABLE II

Experimental Parameters for On-line Preconcentration of Cd(II), Cu(II) and Ni(II) Using PA-SG-loaded Column

\section{Buffer flow rate}

Buffer flow time

Sample flow rate

Sample flow time

Washing rate

Washing time

Eluent

Eluent flow rate

Eluent volume for $\mathrm{Cu}$ and $\mathrm{Ni}$

Eluent volume for $\mathrm{Cd}$
$5 \mathrm{~mL} \mathrm{~min}^{-1}$
$30 \mathrm{~s}$
$5 \mathrm{~mL} \mathrm{~min}^{-1}$
$60 \mathrm{~s}$
$5 \mathrm{~mL} \mathrm{~min}^{-1}$
$30 \mathrm{~s}$
$2 \mathrm{HNO}_{3} \mathrm{~mol} \mathrm{~L}^{-1}$
$5 \mathrm{~mL} \mathrm{~min}^{-1}$
$250 \mu \mathrm{L}$
$500 \mu \mathrm{L}$

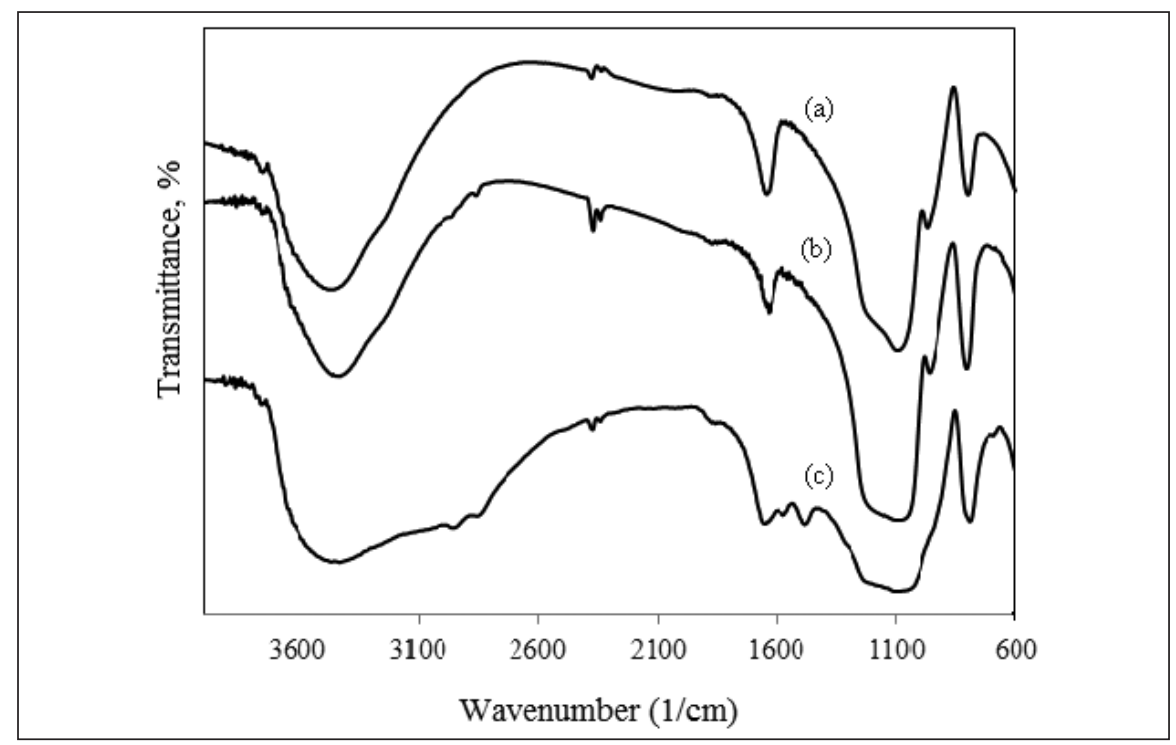

Fig. 3. FT-IR spectra of (a) activated silica gel; (b) 3-chloropropyl bonded silica gel; (c) $P A-S G$. 
The elemental analysis of the modified silica gel (Table III) proved the modification of the silica surface. The amount of PA functional group per gram of the modified silica was calculated to be $0.53 \mathrm{mmol}$ based on the $\mathrm{N}$ content.

\section{Effect of $\mathbf{p H}$}

The $\mathrm{pH}$ of the sample solutions is a highly important factor for the preconcentration, adsorption, and recovery of the trace metal ions. In order to obtain maximum absorbance, the effect of $\mathrm{pH}$ on the sorption of the metal ions was investigated in the $\mathrm{pH}$ range of 1.0-9.0 using suitable buffer solutions. The $\mathrm{pH}$ values for the sample solutions containing $20 \mu \mathrm{g} \mathrm{L}^{-1}$ Cd(II), $0.1 \mathrm{mg} \mathrm{L}^{-1} \mathrm{Cu}(\mathrm{II})$, and 0.1 $\mathrm{mg} \mathrm{L}^{-1} \mathrm{Ni}(\mathrm{II})$ were adjusted to the desired values using suitable acid, base, and buffer solutions. Then, $5 \mathrm{~mL}$ of the sample solutions were passed through the mini-column packed with PA-SG resins at a flow

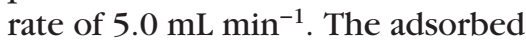
metal ions were eluted with $\mathrm{HNO}_{3}$ $\left(2.0 \mathrm{~mol} \mathrm{~L}^{-1}\right)$ at a flow rate of $5.0 \mathrm{~mL}$ $\min ^{-1}$.

According to the results shown in Figure 4, the absorbance signals were at a $\mathrm{pH}$ below 5 . At a $\mathrm{pH}$ from 5 to 8 , the absorbance values increased and maximum absorbance and sorption efficiency was achieved at a $\mathrm{pH}$ of 8.0. Therefore, the $\mathrm{pH}$ of 8.0 was selected as the optimum $\mathrm{pH}$ for subsequent experiments. In addition, the same experiment was repeated using pure silica. It was found that the metal ions were not retained on the column and thus their absorbance was not observed in the FAAS system. This fact indicates that the retention mechanism of the metal ions is a formation of the chelate at $\mathrm{pH}$ 8.0, not of precipitation.

\section{Effect of Eluent}

In order to determine the most suitable eluent for the elution of the metal ions, $\mathrm{HCl}$ and $\mathrm{HNO}_{3}$ solu- tions were used at different concentrations ranging from 0.5 to $2.5 \mathrm{~mol} \mathrm{~L}^{-1}$. When $2 \mathrm{~mol} \mathrm{~L}^{-1} \mathrm{HNO}_{3}$ was used, the highest absorbance signal was obtained. Therefore, $2 \mathrm{~mol} \mathrm{~L}^{-1} \mathrm{HNO}_{3}$ was selected as an optimum eluent solution. The acid caused a protonation of the PA-SG resin, resulting in a loss of its metal adsorption ability. The protonation of the resin is favored at high concentrations of the acid. Hence, a higher concentration of $\mathrm{HNO}_{3}$ provided a higher absorbance than its dilute concentrations.

\section{Effect of Sample Flow Rate}

The sample flow rate is one of the most important parameters in on-line preconcentration systems. In order to obtain the maximum absorbance value, $5 \mathrm{~mL}$ of the sample was passed through the minicolumn at different flow rates from

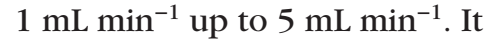
was found that the same absorbance was obtained for all flow rates.

\section{TABLE III}

Elemental Analysis of 3-Chloropropyl and Polyamine Functionalized Silica Gel

\begin{tabular}{llll}
\hline Compound & C (\%) & H (\%) & N (\%) \\
\hline 3-chloropropyl bonded silica gel & 2.11 & 1.12 & - \\
PA-SG & 9.71 & 2.31 & 4.49 \\
\hline
\end{tabular}

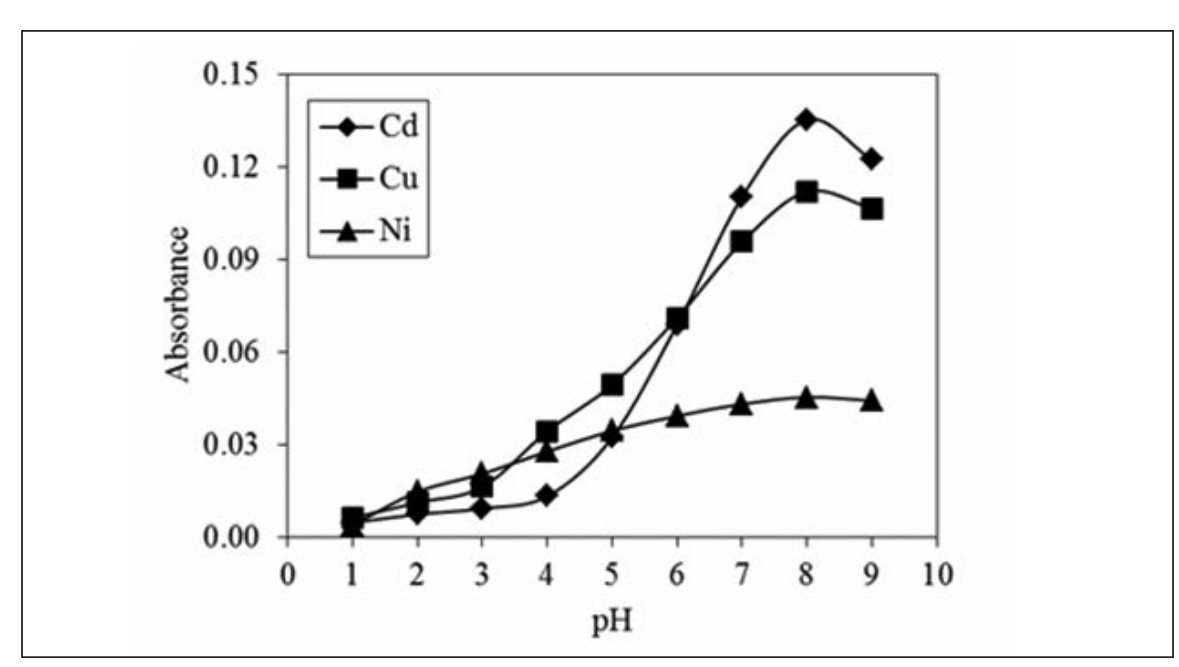

Fig. 4. Effect of $p H$ on the sorption of solutions containing $0.1 \mathrm{mg} \mathrm{L}^{-1} \mathrm{Cu}(\mathrm{II})$,

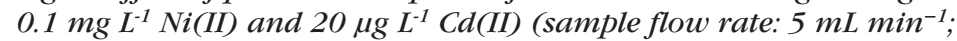

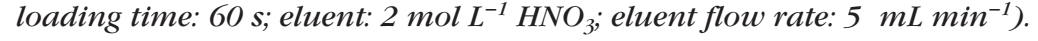




\section{Effect of Potentially Interfering Ions}

The effect of various potentially interfering ions on the absorbance of the $\mathrm{Cd}(\mathrm{II}), \mathrm{Cu}(\mathrm{II})$, and $\mathrm{Ni}(\mathrm{II})$ was examined using $5 \mathrm{~mL}$ of sample solutions containing $20 \mu \mathrm{g} \mathrm{L}^{-1} \mathrm{Cd}(\mathrm{II})$, $0.1 \mathrm{mg} \mathrm{L}^{-1} \mathrm{Cu}(\mathrm{II})$, and $0.1 \mathrm{mg} \mathrm{L}^{-1}$ $\mathrm{Ni}(\mathrm{II})$. The potentially interfering ions were spiked into the sample solution and the developed on-line SPE procedure was applied. The obtained results are listed in Table IV. The findings showed that the absorbance of $\mathrm{Cd}(\mathrm{II}), \mathrm{Cu}(\mathrm{II})$, and $\mathrm{Ni}(\mathrm{II})$ using the on-line SPE method was not significantly affected at the studied levels and that this on-line SPE procedure can be used for the determination of $\mathrm{Cd}(\mathrm{II}), \mathrm{Cu}(\mathrm{II})$, and $\mathrm{Ni}(\mathrm{II})$ ions in highly saline samples such as seawater.

\section{Sorption Capacity of the PA-SG Sorbent}

In order to investigate the sorption capacity of the resin for the analyte ions, $50 \mathrm{mg}$ of the PA-SG and $50 \mathrm{~mL}$ sample solution containing $50 \mathrm{mg} \mathrm{L}^{-1} \mathrm{Cd}(\mathrm{II}), \mathrm{Cu}(\mathrm{II})$, and $\mathrm{Ni}(\mathrm{II})$ were placed in polyethylene flasks and shaken for four hours at ambient temperature. The $\mathrm{pH}$ of the solutions was adjusted to 8.0 with the ammonia-ammonium acetate buffer. After this procedure, the suspensions were filtered off and the amounts of $\mathrm{Cd}(\mathrm{II}), \mathrm{Cu}(\mathrm{II})$, and $\mathrm{Ni}$ (II) in the supernatant were quantified by FAAS. The adsorption capacity of PA-SG was calculated at $41.4,33.1$, and $23.7 \mathrm{mg} \mathrm{g}^{-1}$ for $\mathrm{Cd}(\mathrm{II}), \mathrm{Cu}(\mathrm{II})$, and $\mathrm{Ni}(\mathrm{II})$, respectively.
The stability of PA-SG is very good. The adsorption and desorption properties of PA-SG did not change up to 100 cycles of usage. Thus, its long and useful lifetime is of definite advantage for the proposed method. Some sorbents, for example silica gel modified with the sinapinaldehyde group (48), can be utilized for a limited use period.

\section{Analytical Characteristics of the Developed On-line SPE Method}

A linear calibration graph was plotted by the obtained absorbance for each metal ion from the on-line SPE experiments under the optimized conditions: sample volume $5.0 \mathrm{~mL}$, preconcentration time of 60 seconds, sample flow rate of $5.0 \mathrm{~mL} \mathrm{~min}^{-1}$, eluent flow rate of

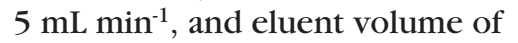
$250 \mu \mathrm{L}$ for $\mathrm{Cu}(\mathrm{II})$ and $\mathrm{Ni}(\mathrm{II})$, and $500 \mu \mathrm{L}$ for Cd(II).

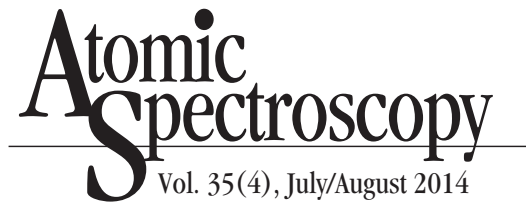

The analytical figures of merit for the analytes are shown in Table $\mathrm{V}$. The limit of detection (LOD) and the limit of quantification (LOQ) were calculated as the amount of analyte necessary to yield a signal equal to three times $(3 \sigma)$ and 10 times $(10 \sigma)$ the standard deviation of the blank signals $(n=11)$, respectively. The enrichment factor (EF) was determined as the ratio of the slopes of the linear section of the calibration graphs before and after preconcentration.

A comparison of the performance of the proposed method with some of the reported procedures based on the on-line preconcentration method is summarized in Table VI. The proposed on-line preconcentration procedure has proven to be a suitable method for the determination of trace levels of $\mathrm{Cd}(\mathrm{II}), \mathrm{Cu}(\mathrm{II})$, and $\mathrm{Ni}$ (II) because of its simple automated operation, high repro-

TABLE IV

Change in Absorbance of Potentially Interfering Ions of Cd(II), Cu(II), and Ni(II) Ions by FI-FAAS Using PA-SG

\begin{tabular}{|c|c|c|c|c|c|}
\hline \multirow{2}{*}{$\begin{array}{l}\text { Matrix } \\
\text { Ions }\end{array}$} & \multirow[t]{2}{*}{ Compounds } & \multirow{2}{*}{$\begin{array}{l}\text { Concentration } \\
\left(\mathrm{mg} \mathrm{L}^{-1}\right)\end{array}$} & \multicolumn{3}{|c|}{ (\%) Change in Absorbance } \\
\hline & & & $\mathrm{Cd}(\mathrm{II})$ & $\mathrm{Cu}(\mathrm{II})$ & $\mathrm{Ni}(\mathrm{II})$ \\
\hline $\mathrm{Cl}^{-}$ & $\mathrm{NaCl}$ & 20,000 & 1.40 & -0.18 & -0.66 \\
\hline $\mathrm{SO}_{4}^{2-}$ & $\mathrm{MgSO}_{4}$ & 4000 & -1.55 & -0.27 & -1.32 \\
\hline $\mathrm{NO}_{3}{ }^{-}$ & $\mathrm{Ca}\left(\mathrm{NO}_{3}\right)_{2}$ & 3100 & 0.15 & -1.70 & -1.32 \\
\hline $\mathrm{PO}_{4}^{3-}$ & $\mathrm{K}_{2} \mathrm{HPO}_{4}$ & 100 & -0.30 & -2.23 & -1.10 \\
\hline $\mathrm{Na}^{+}$ & $\mathrm{NaCl}$ & 12,957 & 1.40 & -0.18 & -0.66 \\
\hline $\mathrm{Ca}^{2+}$ & $\mathrm{Ca}\left(\mathrm{NO}_{3}\right)_{2}$ & 1000 & 0.15 & -1.70 & -1.32 \\
\hline $\mathrm{K}^{+}$ & $\mathrm{KCl}$ & 1000 & -0.37 & -0.45 & -0.88 \\
\hline $\mathrm{Mg}^{2+}$ & $\mathrm{MgSO}_{4}$ & 1000 & -1.55 & -0.27 & -1.32 \\
\hline
\end{tabular}

TABLE V

FI-FAAS Performance for the Determination of $\mathrm{Cd}(\mathrm{II}), \mathrm{Cu}(\mathrm{II})$, and $\mathrm{Ni}(\mathrm{II})$

\begin{tabular}{|c|c|c|c|c|c|c|c|c|}
\hline \multirow{2}{*}{$\begin{array}{l}\text { Metal } \\
\text { Ions }\end{array}$} & \multirow[b]{2}{*}{$\begin{array}{c}\mathrm{LOD} \\
\left(\mu \mathrm{g} \mathrm{L}^{-1}\right)\end{array}$} & \multicolumn{3}{|c|}{ Preconcentration Method } & \multicolumn{3}{|c|}{ Direct Method } & \multirow[b]{2}{*}{$\mathrm{EF}$} \\
\hline & & $\begin{array}{c}\mathrm{LOQ} \\
\left(\mu \mathrm{g} \mathrm{L}^{-1}\right)\end{array}$ & $\begin{array}{l}\text { Working } \\
\text { Range } \\
\left(\mu \mathrm{g} \mathrm{L}^{-1}\right)\end{array}$ & $\begin{array}{c}\text { Calibration } \\
\text { Equation }\end{array}$ & $\begin{array}{c}\text { LOD } \\
\left(\mu \mathrm{g} \mathrm{L}^{-1}\right)\end{array}$ & $\begin{array}{c}\mathrm{LOQ} \\
\left(\mu \mathrm{g} \mathrm{L}^{-1}\right)\end{array}$ & $\begin{array}{c}\text { Calibration } \\
\text { Equation }\end{array}$ & \\
\hline $\mathrm{Cd}(\mathrm{II})$ & 0.19 & 0.61 & $10-200$ & $\mathrm{Abs}=3.244 \mathrm{C}+8.5 \times 10^{-2}$ & 7.44 & 24.85 & $\mathrm{Abs}=0.0813 \mathrm{C}+1.3 \times 10^{-3}$ & 39.90 \\
\hline $\mathrm{Cu}(\mathrm{II})$ & 0.73 & 2.40 & $10-200$ & $\mathrm{Abs}=1.105 \mathrm{C}+1.6 \times 10^{-3}$ & 16.67 & 55.65 & $\mathrm{Abs}=0.0363 \mathrm{C}+8.2 \times 10^{-4}$ & 30.44 \\
\hline $\mathrm{Ni}(\mathrm{II})$ & 0.91 & 3.02 & $10-200$ & $\mathrm{Abs}=0.445 \mathrm{C}+4.9 \times 10^{-3}$ & 39.55 & 131.37 & $\mathrm{Abs}=0.0102 \mathrm{C}+1.1 \times 10^{-3}$ & 43.63 \\
\hline
\end{tabular}

$\mathrm{EF}=$ Enrichment Factor. 
ducibility, larger enrichment factor, and lower detection limits.

\section{Accuracy of the Proposed Method}

The accuracy of the proposed method was analyzed by measuring the $\mathrm{Cd}(\mathrm{II}), \mathrm{Cu}(\mathrm{II})$, and $\mathrm{Ni}$ (II) levels in certified reference material CTAVTL-2 Virginia Tobacco Leaves and NWTM-15.2 Water - Trace Elements. The results given Table VII show that the concentration of Cd(II), $\mathrm{Ni}(\mathrm{II})$, and $\mathrm{Cu}(\mathrm{II})$ was accurately determined and is in close agreement with the certified values. The Student's $t$-test (at $\mathrm{p}<0.05$ ) was applied to the obtained and the certified results. It was found that there is no significant difference between the obtained results and the certified values of the samples.

The accuracy of the on-line SPE method was also checked by performing a spiking and recovery test of the Cd(II), Cu(II), and $\mathrm{Ni}(\mathrm{II})$ ions in a synthetic seawater sample. The obtained results (Table VIII) indicate that using the proposed method they were in good agreement with the concentrations of the synthetic seawater values.

\section{Application of the Proposed Method}

The proposed on-line SPE method was used for the determination of $\mathrm{Cd}(\mathrm{II}), \mathrm{Cu}(\mathrm{II})$, and $\mathrm{Ni}(\mathrm{II})$ levels in environmental water samples such as river, gulf, lake, and tap water. The concentrations of $\mathrm{Cd}(\mathrm{II}), \mathrm{Cu}(\mathrm{II})$, and $\mathrm{Ni}$ (II) in these water samples were also measured with the ICP-MS for comparison and with the on-line SPE method. The results obtained are listed in Table IX. The Student's $t$-test (at $\mathrm{p}<0.05$ ) was applied to the values obtained by the on-line SPE method and the ICP-MS technique. The results of the Student's $t$-test showed that there is no significant difference between the results obtained by the proposed method and those obtained by ICP-MS.
Thus, it can be concluded that the proposed method is reliable and suitable using the conditions as provided above.

The FI-FAAS method was also applied to solid food samples such as chicken and tea for measure-

TABLE VI

Comparison of Analytical Performance of Proposed Method With Other Techniques in which FAAS is Used as Detection Technique

\begin{tabular}{|c|c|c|c|c|c|c|c|}
\hline Sorbent & $\begin{array}{l}\mathrm{F} \\
\mathrm{Cu}(\mathrm{II})\end{array}$ & $\begin{array}{l}\text { richme } \\
\text { actor ( } \\
\text { Cd(II) }\end{array}$ & $\begin{array}{l}\text { nt } \\
\text { EF) } \\
\mathrm{Ni}(\mathrm{II})\end{array}$ & $\mathrm{Cu}(\mathrm{II})$ & $\begin{array}{l}\mathrm{LOD} \\
\left.\mu_{\mathrm{gg} \mathrm{L}}^{-1}\right) \\
\mathrm{Cd}(\mathrm{II})\end{array}$ & $\mathrm{Ni}(\mathrm{II})$ & Ref. \\
\hline $\mathrm{Nb}_{2} \mathrm{O}_{5}-\mathrm{SiO}_{2}$ & 34.1 & 33.0 & - & 0.4 & 0.1 & - & (2) \\
\hline $\begin{array}{l}\text { Dithizone Immobilized } \\
\text { Silica Gel }\end{array}$ & 42.6 & - & - & 0.2 & - & - & (49) \\
\hline 1,10-Phenanthroline & 32.0 & 32.0 & - & 0.3 & 0.5 & 50 & \\
\hline Dimethylglyoxime & - & - & 21.0 & - & - & 3 & $(51)$ \\
\hline $\begin{array}{l}\text { ToyopearlAF-Chelate } \\
650 \mathrm{M}\end{array}$ & - & - & - & 0.017 & 0.0014 & $4 \quad 0.028$ & $(52)$ \\
\hline $\mathrm{Al}_{2} \mathrm{O}_{3} / \mathrm{MWCNT}$ & - & - & 20.9 & - & - & 4.1 & $(28)$ \\
\hline AG50W-X8 resin & 23.0 & 46.0 & 18.0 & 0.1 & 0.08 & 3 & (53) \\
\hline Polyamine Silica & 39.9 & 30.4 & 43.6 & 0.19 & 0.73 & 0.91 & $\begin{array}{l}\text { This } \\
\text { work }\end{array}$ \\
\hline
\end{tabular}

$\mathrm{EF}=$ Enrichment Factor. $\quad$ Ref. $=$ Reference.

TABLE VII

Determination of $\mathrm{Cd}$ (II), Cu(II), and Ni(II) Levels in Standard Reference Materials Using Proposed FI-FAAS Method

\begin{tabular}{ccccc}
\hline Metal Ions & \multicolumn{2}{c}{ CTA-VTL-2 } & \multicolumn{2}{c}{ NWTM-15.2 } \\
& $\begin{array}{c}\text { Virginia Tobacco Leaves } \\
\text { Certified } \\
\left(\mu \mathrm{g} \mathrm{L}^{-1}\right)\end{array}$ & $\begin{array}{c}\text { Observed } \\
\left(\mu \mathrm{g} \mathrm{L}^{-1}\right)\end{array}$ & $\begin{array}{c}\text { Water - Trace Elements } \\
\text { Certified } \\
\left(\mu \mathrm{g} \mathrm{L}^{-1}\right)\end{array}$ & $\begin{array}{c}\text { Observed } \\
\left(\mu \mathrm{g} \mathrm{L}^{-1}\right)\end{array}$ \\
\hline $\mathrm{Cd}(\mathrm{II})$ & $1.52 \pm 0.17$ & $1.5 \pm 0.1$ & $13.0 \pm 1.1$ & $12.8 \pm 0.3$ \\
$\mathrm{Cu}(\mathrm{II})$ & $18.2 \pm 0.9$ & $17.6 \pm 0.7$ & $17.3 \pm 1.6$ & $17.0 \pm 0.4$ \\
$\mathrm{Ni}(\mathrm{II})$ & $1.98 \pm 0.21$ & $1.9 \pm 0.3$ & $17.7 \pm 1.7$ & $16.9 \pm 0.5$ \\
\hline
\end{tabular}

TABLE VIII

Spiking/Recovery Test of Cd(II), Cu(II), and Ni(II) Ions From Synthetic Seawater Using Proposed FI-FAAS Method

\begin{tabular}{ccccccc}
\hline $\begin{array}{c}\text { Added } \\
\left(\mu \mathrm{g} \mathrm{L}^{-1}\right)\end{array}$ & $\mathrm{Cd}(\mathrm{II})$ & $\begin{array}{c}\text { Measured } \\
\left(\mu \mathrm{g} \mathrm{L}^{-1}\right)\end{array}$ & $\mathrm{Cu}(\mathrm{II})$ & $\mathrm{Ni}(\mathrm{II})$ & \multicolumn{3}{c}{$\begin{array}{c}\text { Recovery } \\
(\%)\end{array}$} \\
\hline 10 & $9.7 \pm 0.2$ & $9.6 \pm 0.4$ & $9.5 \pm 0.5$ & 97.0 & 96.0 & 95.0 \\
20 & $19.5 \pm 0.4$ & $19.3 \pm 0.7$ & $19.7 \pm 0.6$ & 97.5 & 96.5 & 98.5 \\
30 & $29.6 \pm 0.5$ & $29.2 \pm 0.3$ & $29.1 \pm 0.2$ & 98.7 & 97.3 & 97.0 \\
\hline
\end{tabular}




\section{CONCLUSION}

In this study, PA-SG as a novel sorbent material was prepared and characterized. The PA-SG sorbent showed good affinity to $\mathrm{Cd}(\mathrm{II})$, $\mathrm{Cu}(\mathrm{II})$, and $\mathrm{Ni}$ (II) ions at a $\mathrm{pH}$ of 8.0 in an on-line preconcentration system. The resin can be used at high flow rates of sample solution enabling high frequency sample analysis. Another advantage of the PA-SG is its long useful lifetime with at least 100 cycles. PA-SG has a high sorption capacity of Cd(II), $\mathrm{Cu}(\mathrm{II})$, and $\mathrm{Ni}(\mathrm{II})$ ions. PA-SG exhibited fast adsorption and desorption properties which are the main features required for a superior sorbent. The developed on-line preconcentration method is very efficient for use in the determination of $\mathrm{Cd}(\mathrm{II}), \mathrm{Cu}(\mathrm{II})$, and $\mathrm{Ni}(\mathrm{II})$ owing to its simplicity, automation, ease of use, low detection limits, high speed, accuracy, and good selectivity. Consequently, PA-SG can be successfully used for the online preconcentration and determination of $\mathrm{Cd}(\mathrm{II}), \mathrm{Cu}(\mathrm{II})$, and $\mathrm{Ni}(\mathrm{II})$ in natural water and food samples.

The possible use of PA-SG for other elements such as $\mathrm{As}, \mathrm{Pb}$, and $\mathrm{Hg}$ could be studied for the solid phase extraction and determination in different samples such as water, food, and ores in further research studies.
TABLE IX

Comparison of Proposed FI-FAAS Method and ICP-MS Technique for the Determination of Cd(II), Cu(II), and Ni(II) Levels in Various Water Samples

\begin{tabular}{|c|c|c|c|}
\hline \multirow[t]{2}{*}{ Sample } & \multirow[t]{2}{*}{ Element } & \multicolumn{2}{|c|}{ Found Value $\left(\mu \mathrm{g} \mathrm{L}^{-1}\right)$} \\
\hline & & FI-FAAS & ICP-MS \\
\hline \multirow[t]{3}{*}{ Sakarya River } & Cd(II) & $<\mathrm{LOQ}$ & $0.52 \pm 0.02$ \\
\hline & $\mathrm{Cu}(\mathrm{II})$ & $10.82 \pm 0.96$ & $9.98 \pm 0.14$ \\
\hline & $\mathrm{Ni}(\mathrm{II})$ & $21.33 \pm 0.84$ & $23.59 \pm 0.57$ \\
\hline \multirow[t]{3}{*}{ Izmit Gulf } & Cd(II) & $<\mathrm{LOQ}$ & $0.02 \pm 0.006$ \\
\hline & $\mathrm{Cu}(\mathrm{II})$ & $12.42 \pm 0.25$ & $11.84 \pm 0.70$ \\
\hline & $\mathrm{Ni}(\mathrm{II})$ & $42.24 \pm 1.29$ & $40.86 \pm 0.99$ \\
\hline \multirow[t]{3}{*}{ Seawater } & Cd(II) & $<\mathrm{LOQ}$ & $0.03 \pm 0.003$ \\
\hline & $\mathrm{Cu}(\mathrm{II})$ & $6.4 \pm 0.14$ & $6.69 \pm 0.21$ \\
\hline & $\mathrm{Ni}(\mathrm{II})$ & $13.91 \pm 0.22$ & $14.43 \pm 0.31$ \\
\hline \multirow[t]{3}{*}{ Tap Water } & Cd(II) & $<\mathrm{LOQ}$ & $0.06 \pm 0.003$ \\
\hline & $\mathrm{Cu}(\mathrm{II})$ & $2.38 \pm 0.08$ & $2.47 \pm 0.25$ \\
\hline & $\mathrm{Ni}(\mathrm{II})$ & $1.9 \pm 0.16$ & $1.86 \pm 0.06$ \\
\hline \multicolumn{4}{|c|}{$\begin{array}{c}\text { TABLE X } \\
\text { Determination of Cd(II), Cu(II), and Ni(II) Levels } \\
\text { in Chicken and Tea Samples Using Proposed FI-FAAS Method }\end{array}$} \\
\hline Metal Ions & Chick & $\left.\mathrm{dg} \mathrm{g}^{-1}\right) \pm \mathrm{s}$ & Tea $\left(\mu g g^{-1}\right) \pm s$ \\
\hline Cd(II) & & & $1.08 \pm 0.02$ \\
\hline $\mathrm{Cu}(\mathrm{II})$ & & 0.03 & $14.2 \pm 1.3$ \\
\hline $\mathrm{Ni}(\mathrm{II})$ & & 0.04 & $16.3 \pm 1.1$ \\
\hline
\end{tabular}

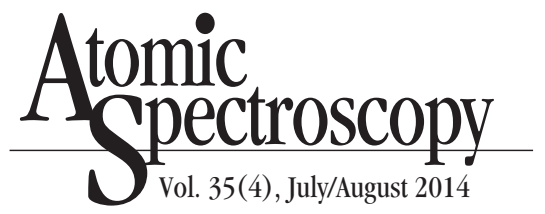

ACKNOWLEDGMENT

This work was supported by the Sakarya University Research Fund with Project Number 2012-50-02036.

Received December 14, 2013. 


\section{REFERENCES}

1. L.M. Costa, E.S. Ribeiro, M.G. Segatelli, D.R. Nascimento, F.M. Oliveira, and C.R.T. Tarley, Spectrochim. Acta Part B 66(5), 329 (2011).

2. M. Imamoglu, J. Disper, Sci. Technol. 34(9), 1183 (2013).

3. S. Sivrikaya, S. Albayrak, M. Imamoglu, A. Gundogdu, C. Duran, and H. Yildiz, Desalin. Water Treatment 50, 2 (2012).

4. M. Imamoglu, A. Vural and $\mathrm{H}$. Altundag, Desalin. Water Treat. In Press. (2013). doi:10.1080/19443994.2013.834515

5. M. Imamoglu and O. Tekir, Desalination 228(1-3), 108 (2008).

6. M. Yaman and E. Eral, At. Spectrosc. 33, 212 (2012).

7. M. Yaman and E. Eral, Int. J. Environ. Res. 7, 989 (2013).

8. A. Duran, M. Tuzen and M. Soylak, At. Spectrosc. 34, 99 (2013)

9. D. Kara and A. Fisher, Sep. Purif. Rev. 41, 267 (2012).

10. D. Kara, A. Fisher, M. Foulkes and S.J. Hill, Spectrochim. Acta Part A 75, 361 (2010).

11. V.A. Lemos, and E. M. Gama, Environ. Monit. Assess. 171, 163 (2010).

12. S.Z. Chen, X.L. Guo, Y.Y. He and D.B. Lu, At. Spectrosc. 34(4), 113 (2013).

13. G. Ozcelik, M. Imamoglu, S.Z. Yildiz, and D. Kara, Water Air Soil Poll. 223(8), 5391 (2012).

14. E. Kilinc, A. Dundar, S. Ozdemir and V. Okumus, At. Spectrosc. $34(4), 133$ (2013).

15. D. Kara, A. Fisher and S.J. Hill, J. Hazard. Mater. 165, 1165 (2009).

16. V.A. Lemos, C.G. Novaes and M.A. Bezerra, J. Food Compos. Anal. 22, 337 (2009).

17.D. Mendil, H. Bardak, M. Tuzen and M. Soylak, Talanta 107, 162 (2013).

18. S. Sivrikaya, H. Altundag, M. Zengin, and M. Imamoglu, Sep. Sci. Technol. 46, 2032 (2011).
19. I. Durukan, M. Soylak and M. Dogan, At. Spectrosc. 34(1), 20 (2013)

20. Y.Z. Yi, S.Y. Wu, S.J. Jiang and A.C. Sahayam, At. Spectrosc. 34(2), 39 (2013).

21. M. Soylak and E. Yilmaz, At. Spectrosc. 34(1), 15 (2013).

22. D. Mendil, J. Food Sci. 77(9), 181 (2012).

23. E. Kilinc, A. Dundar, S. Ozdemir, and V. Okumus, At. Spectrosc. 34(3), 78 (2013).

24. A. Tobiasz, S. Walas, A.S. Hernández and $\mathrm{H}$. Mrowiec, Talanta 96, 89 (2012)

25. M. Imamoglu and V.Gunes, At. Spectrosc. 33, 205 (2012).

26. E. Akyuz, M. Imamoglu and H. Altundag, At. Spectrosc. 34 (4), 146 (2013).

27. E. Akdemir and M. Imamoglu, Desalin. Water Treat. In Press. (2013). doi.1080/19443994.2013.813004

28. L.A. Escudero, S. Cerutti, R.A. Olsina, J.A. Salonia and J.A. Gasquez, J Hazard Mater.183, 218 (2010).

29. C. Karadaş, O. Turhan, and D. Kara, Food Chem. 141, 655 (2013).

30. C. Duran, D. Ozdes, A. Gundogdu, M. Imamoglu and H.B. Senturk, Anal. Chim. Acta 688, 75 (2011).

31. S. Sivrikaya, E. Cerrahoglu, M. Imamoglu and M. Arslan, Toxicol. Environ. Chem. 95(6), 899 (2013).

32. C. Er, B.F. Senkal and M. Yaman, Food Chem. 137, 55 (2013).

33. M. Soylak and I. Murat, Food Anal. Method. 5, 1003 (2012).

34. S.Z. Chen, Y.Y. He, D.B. Lu and X.L. Guo, At. Spectrosc. 34(3), 73 (2013).

35. M. Doğan, Y. Turhan, M. Alkan, H. Namli, P. Turan and O. Demirbaş, Desalination 230, 248 (2008).

36. M. Imamoglu and A.O. Aydin, Fresen. Environ. Bull. 14(10), 940 (2005).

37. M. Imamoglu and S. Albayrak, At. Spectrosc.33(1), 30 (2012).
38. P.E. Franco, M.T. Veit, C.E. Borba, G.C. Gonçalves, M.R.F. Klen, R. Bergamasco, E. A. Silva and P.Y.R. Suzaki, Chem. Eng. J. 221, 426 (2013).

39. G. F. Lima, V.S. Ferreira, N.V. Godoy, R.F. Medeiros, F.M.S. Garrido, E.S. Ribeiro, S. Nakagaki, M.G. Segatelli, M.A. Bezerra and C.R.T. Tarley, Microchem. J. 109, 98 (2013).

40. A.N. Anthemidis, S. Xidia and G. Giakisikli, Talanta 97, 181 (2012).

41. Z.A. Chandio, F.N. Talpur, H.I. Afridi, H. Khan, G.Q. Khaskheli and M.I. Khaskheli, Anal. Methods 5(17), 4425 (2013).

42. S.Shahida, A. Ali, M.H. Khan and M.M.Saeed, Environ.Monit. Assess. 185, 1613 (2013).

43. C. Karadas and D. Kara, J. AOAC Int. 96(3), 642 (2013)

44. S.F.J. Veguería, J.M. Godoy, R.C. Campos and R. A. Gonçalves, Microchem. J. 106, 121 (2013).

45. J. Ye, S. Liu, M. Tian, W. Li, B. Hu, W. Zhou and Q. Jia, Talanta, 118, 231 (2014)

46. E.M. Soliman, Anal. Lett. 30(9), 1739 (1997).

47. J.E. Cantle, Atomic Absorption Spectrometry, Elsevier Scientific Publishing Company, (1982).

48. L.J. Zhang, X. Hu, C.Z. Yu, R. Crawford and A.M. Yu, Int. J. Environ. An. Ch. 93, 1274 (2013).

49. H.M. Yu, H. Song, and M. L. Chen. Talanta 85, 625 (2011).

50. A. Ali, X. Yin, H. Shen, Y. Ye, and X. Gu, Anal. Chim Acta. 392, 283 (1999).

51. A. Ali, Y. Ye, G. Xu, X. Yin and T. Zhang. Microchem. J. 63, 365 (1999).

52. N.G. Beck, R.P. Franks and K.W.Bruland, Anal. Chim.Acta 455, 11 (2002).

53. A.A. Menegario and M.F. Gine, Spectrochim. Acta Part B 56, 917 (2001). 